\title{
HDAC3 Gene
}

National Cancer Institute

\section{Source}

National Cancer Institute. HDAC3 Gene. NCI Thesaurus. Code C26497.

This gene plays a role in chromatin remodeling, repression of gene expression and modulation of both cell growth and apoptosis. 